\title{
Comparison of the Effects of 4-CPA and CPPU Treatment on Melon Cell Size and Sugar Accumulation
}

\author{
Yasutaka KANO \\ Ishikawa Agricultural College, Nonoichi, Ishikawa 921-8836, Japan
}

(Received August 13, 2004)

\begin{abstract}
Melon (Cucumis melo L.) fruits was respectively treated with solutions of $500 \mathrm{mg} \mathrm{L}^{-1}$ of 4CPA (4-chlorophenoxyaceticacid) and $20 \mathrm{mg} \mathrm{L}^{-1}$ of CPPU (2-chloro-4-pyridyl-N-phenylurea) and then cell size and sugar accumulation in the fruit were investigated. The mean number of cells larger than $200 \mu \mathrm{m}$ for each rectangular parallelepiped (7-mm long sample serially collected beginning at one end of the $10-\mathrm{mm}$ wide strip removed from the 10-mm thick disk at the maximum transverse diameter of the fruit to the opposite end. Designated as a sample) of the 4-CPA and the CPPU-treated fruits on the 40th day after anthesis (DAA) was 1.4 times higher than that of the control. The mean number of cells smaller than $200 \mu \mathrm{m}$ per sample of the CPPU-treated fruits on the 55th DAA was 6.5 times higher than that of the control. Mean sucrose content per sample of the 4-CPA and the CPPU on the 55th DAA was 1.7 times as much as that of the control, and the mean glucose and fructose content of the CPPU-treated fruit on the 55th DAA was the highest, being 1.5 times higher than that of the control. Thus, it might be considered that the earlier increase in the number of larger cells in the 4-CPA- and the CPPU-treated melon fruits is related to a larger content of sucrose, and the increase in the number of small cells during the latter period of the CPPU-treated fruits participates in the largest content of glucose and fructose.
\end{abstract}

Keywords : cell size, 4-chlorophenoxyaceticacid, 2-chloro-4-pyridyl-N-phenylurea, netted melon, sugar accumulation

\section{INTRODUCTION}

Sucrose is the main sugar accumulating in melons (Hayata et al., 2000; Kano, 2000; Li et al., 2000; Motomura et al., 1989; Nagao and Nakazumi, 1995) at harvest time. Melon fruit at harvest time contains a large number of cells about $600 \mu \mathrm{m}$ in diameter (Kano, 2000). Additionally, sucrose accumulates rapidly in the late growing stages in melon fruit with large cells (Kano, 2004). The primary sugar accumulation in grapes is fructose and glucose (Matsui et al., 1979), and the cell size of grapes is about $300 \mu \mathrm{m}$ maximum at harvest time (Nakagawa and Nanjou, 1965). Fructose accumulates intensively in Japanese pears (Hirata et al., 1969) containing cells of about $200 \mu \mathrm{m}$ in size (Toyama and Hayashi, 1957). These results suggest that the kind of sugars accumulated in fruits is closely related with cell size in fruits.

Auxin promotes cell enlargement (Collet et al., 2000; Jones et al., 1998; Masuda, 1990). The promotion of fruit development was recognized in melons (Li et al., 2000) and tomatoes (Hayata et al., 1995) using a treatment of 4-CPA (4-chlorophenoxyaceticacid), one of the synthetic auxins. Furthermore, as the treatment of $500 \mathrm{mg} \mathrm{L}^{-1}$ of 4-CPA to melon fruit increased fruit weight (Hayata

Corresponding author: Yasutaka Kano, fax : +81-76-227-7443, e-mail : gansho@ishikawa-pu.ac.jp 
et al., 2000), in this experiment the solution of $500 \mathrm{mg} \mathrm{L}^{-1}$ was employed for 4-CPA. In addition, CPPU (2-chloro-4-pyridyl-N-phenylurea), one of the synthetic cytokinins accelerates fruit growth of grapes by cell division (Nickell, 1986). Since the number of cells in melon fruit increased by the treatment of $20 \mathrm{mg} \mathrm{L}^{-1}$ of CPPU (Ikeda et al., 1990), a solution of $20 \mathrm{mg} \mathrm{L}^{-1}$ was used for CPPU for this experiment. Moreover, cytokinins have also roles in the promotion of cell enlargement (Denizci, 1966).

It is therefore reasonable to consider that auxin and cytokinin have a great influence on cell size and sugar accumulation in melon fruits. In this paper, the effects of 4-CPA and CPPU on cell size and sugar accumulation in melon fruits were investigated.

\section{MATERIALS AND METHODS}

Earl's Knight Natsukei No.2 (Cucumis melo L.) melon seeds were planted on the seed bed on April 20th, 2000, and nursery plants were spaced at $40 \mathrm{~cm}$ intervals in a plastic film greenhouse on May 10th. The flowers that opened around June 15th were used in this experiment. Fruits on the 20th DAA (day after anthesis) were fully sprayed with a $500 \mathrm{mg} \mathrm{L}^{-1}(2.68 \mathrm{mM})$ of 4-CPA solution and with a $20 \mathrm{mg} \mathrm{L}^{-1}(0.10 \mathrm{mM})$ of CPPU solution. Five fruits were collected on the 40 th and the 55th DAA in each treatment, and fruit weights on the 40th and the 55th DAA were investigated. One fruit whose weight was the closest to the average weight for each treatment was chosen, and these fruits were used for cell and sugar analysis.

The most average fruit undergoing each treatment was cut at the maximum transverse diameter, and two approximately $10-\mathrm{mm}$ thick disks from each average fruit from each treatment were excised, one from the maximum transverse diameter toward the calyx end for cell analysis and one from the maximum transverse diameter toward the peduncle end for sugar analysis (Fig. 1). Using a sharp table knife, one strip, $10 \mathrm{~mm}$ wide and $10 \mathrm{~mm}$ deep, was removed from the disk with $5 \mathrm{~mm}$ straddling the maximum transverse diameter line across each disk. Rectangular parallelepipeds which were $7 \mathrm{~mm}$ long, $10 \mathrm{~mm}$ wide and $10 \mathrm{~mm}$ deep (designated as samples) each were serially collected using the same sharp table knife beginning at one end of the strip, proceeding across to the opposite end of the strip. All of the samples in each treatment, other than two end blocks con-

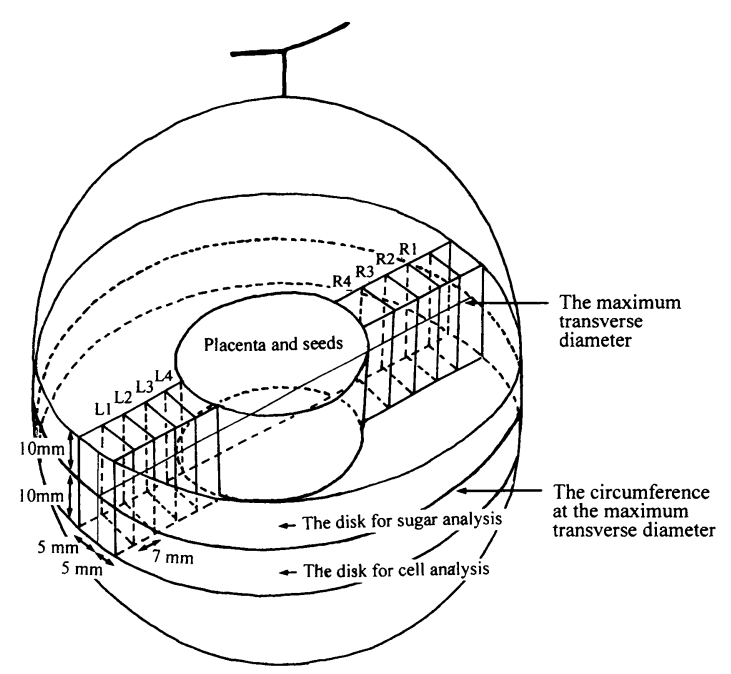

Fig. 1 An illustration of the collection of rectangular parallelepiped parts for the determination of the size and number of cells and sugar content in melon fruits. This is an example for 4-CPA-treated fruits. 
taining the epidermis, were used. These samples in each treatment were dehydrated using various concentrations of alcohol $(70 \%, 80 \%, 90 \%$ and $100 \%)$ and were then imbedded in paraffin. Seven $10 \mu \mathrm{m}$-thick sections were prepared from these paraffin blocks, and the clearest section from each sample of each treatment was examined under a microscope. As shown in Fig. 2, the maximum diameter of individual cells on the maximum transverse diameter in each sample of the fruit were measured.

Each sample ( $7 \mathrm{~mm}$ in length, $10 \mathrm{~mm}$ in width and $10 \mathrm{~mm}$ in depth) other than two end samples containing the epidermis were wrapped with cheesecloth and squeezed by pincers to get juice. The juice was diluted 10 times with distilled water. The solution was centrifuged at $8,000 \times \mathrm{g}$ for $15 \mathrm{~min}$, and then filtered through a $0.45-\mu \mathrm{m}$ filter (Millipore, $0.45 \mu \mathrm{m}$ PTFE, hydrophilic). Twenty $\mu \mathrm{L}$ of the filtrate was injected into HPLC (Shimadzu Inc., Japan) fitted with a refractive index detector (RID. Shimadzu Inc., Japan), equipped with Shim-pack SCR-101C (Shimadzu Inc., Japan), at $0.8 \mathrm{~mL} \mathrm{~min}^{-1}$ at $80^{\circ} \mathrm{C}$. For assessment of the presence and concentrations of each sugar, solutions of $20 \mathrm{~g} \mathrm{~L}^{-1}$ of sucrose, glucose and fructose were injected into the HPLC before injection of the filtrates. The mean content of sucrose, glucose and fructose was calculated by dividing total sucrose, glucose and fructose contents by the number of the samples.

\section{RESULTS}

The weight in the 4-CPA-treated fruits on the 40th DAA was the largest among the fruit treated, but the weight of fruits on the 55th DAA was not significantly different among the treatments (Fig. 3). Cells of the control 40 DAA were dispersed from $50 \mu \mathrm{m}$ to $400 \mu \mathrm{m}$, centering 200 $\mu \mathrm{m}$ but cells of the 4-CPA and the CPPU 40 DAA were dispersed in a range larger than $200 \mu \mathrm{m}$

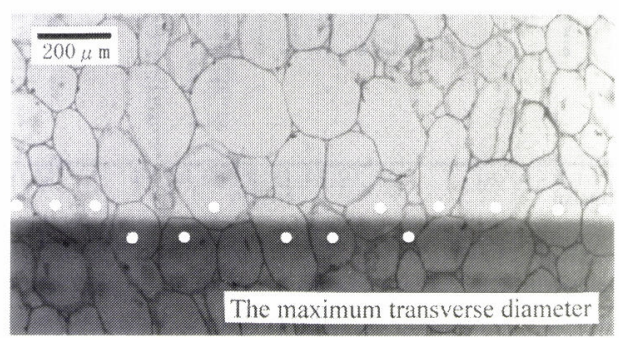

Fig. 2 An illustration of the measurement of the size and the number of cells of melon fruits 40 days after anthesis. White dots indicate the actual cells measured.

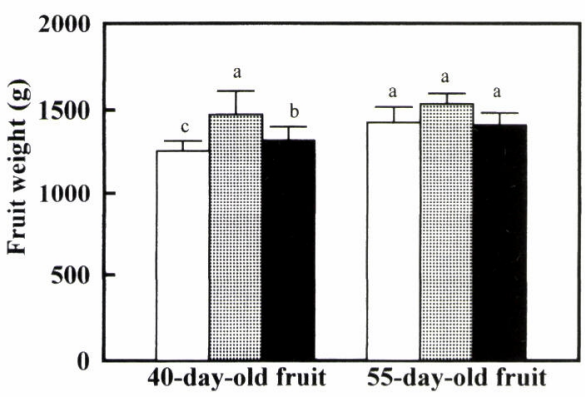

Fig. 3 Comparison of the weight among the fruits of the control (open column), 4-CPA-(dotted column) and CPPU-treated (solid column) samples. 40 and 55-day-old fruit; the fruit 40 and 55 days after anthesis, respectively. Values with different letters are significantly different at $P<0.05$ using LSD test. Vertical bars are SD $(n=4)$. 
(Fig. 4). While cells of the control and the 4-CPA 55 DAA were dispersed widely from $50 \mu \mathrm{m}$ to $600 \mu \mathrm{m}$, cells of the CPPU were scattered particularly in a range smaller than $200 \mu \mathrm{m}$. The number of samples containing 20 or more cells which were larger than $200 \mu \mathrm{m}$ in the 4-CPA and the CPPU 40 DAA were twice as large as that of the control, but the number of samples containing 20 and more cells larger than $200 \mu \mathrm{m} 55$ DAA was nearly the same among the treatments (Fig. 5). The number of samples containing 10 and more cells smaller than $200 \mu \mathrm{m}$ in the CPPU 55 DAA was
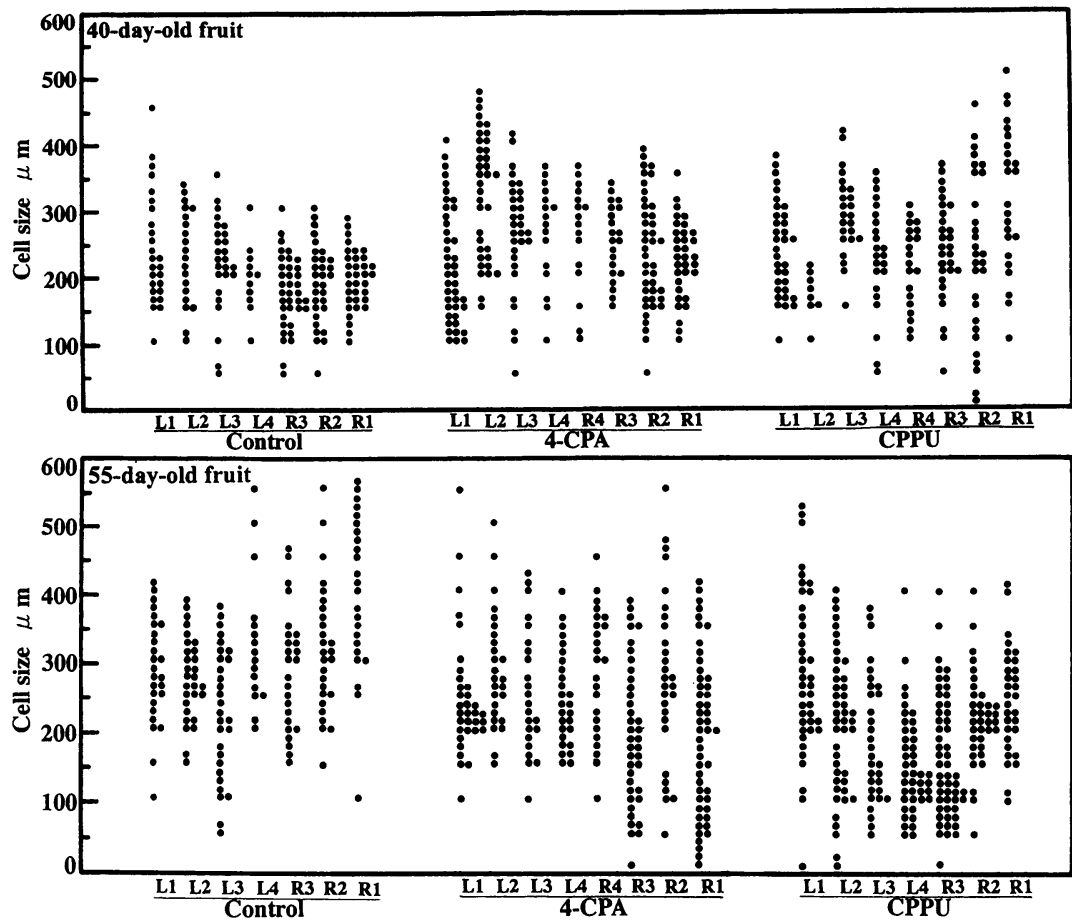

Fig. 4 Comparison of the effects of 4-CPA and CPPU on the size and the number of cells in each rectangular parallelepiped of the fruits. All cells in each rectangular parallelepiped were divided into $50 \mu \mathrm{m}$ segments each from 0 to $600 \mu \mathrm{m}$, and the number of cells for each $50 \mu \mathrm{m}$ were dotted. The symbols under the figures are equivalent to those in Fig. 1.

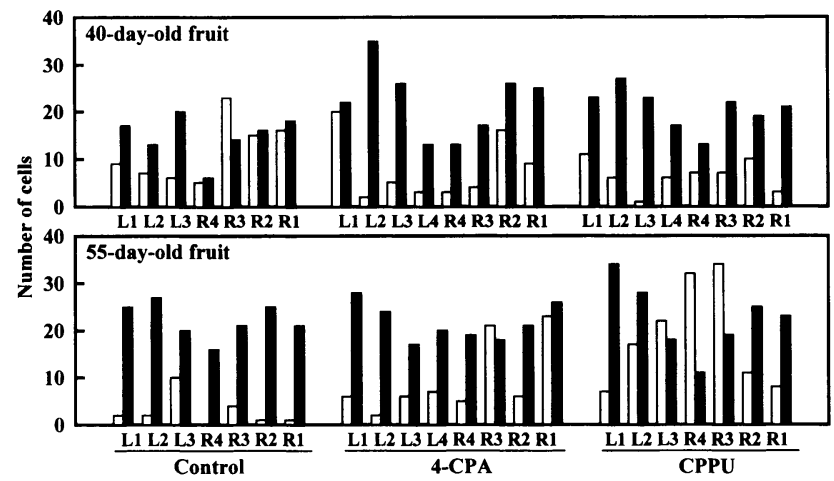

Fig. 5 Comparison of the effects of 4-CPA and CPPU on the number of cells smaller (open column) and larger (solid column) than $200 \mu \mathrm{m}$ in each rectangular parallelepiped of the fruits. The symbols under the figures are equivalent to those in Fig. 1. 


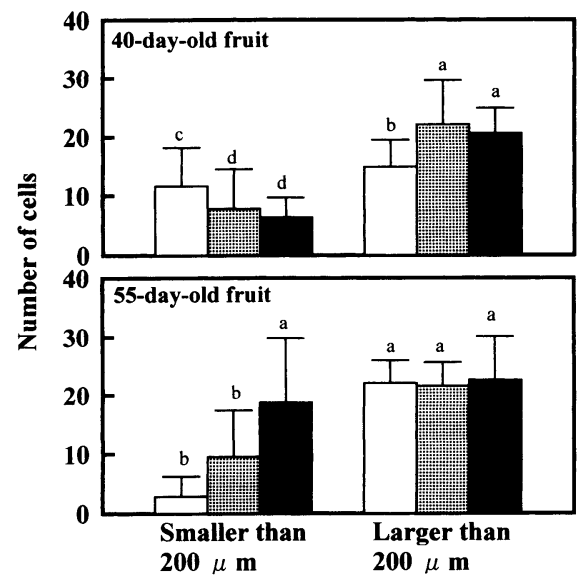

Fig. 6 Comparison of the effects of 4-CPA and CPPU on the mean number of cells smaller and larger than $200 \mu \mathrm{m}$ in melon fruits. Open column; control. Dotted column; treated with 4-CPA. Solid column; treated with CPPU. Values with different letters are significantly different at $P<0.05$ using LSD test. Vertical bars are SD $(n=7-8)$.

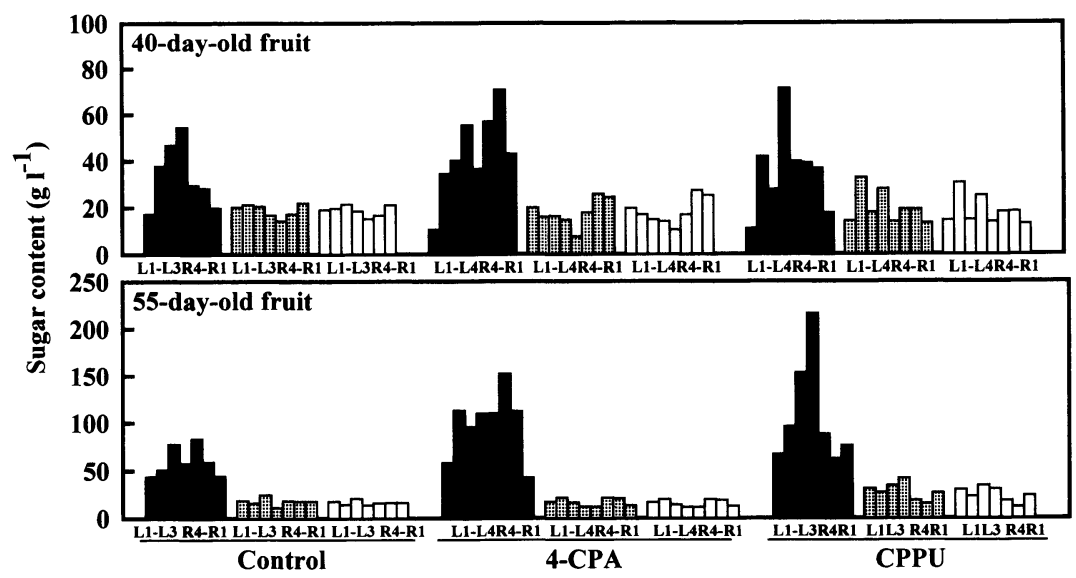

Fig. 7 Comparison of the effects of 4-CPA and CPPU on the content of sucrose (solid column), glucose (dotted column) and fructose (open column) in each rectangular parallelepiped of melon fruits. The symbols under the figures are equivalent to those in Fig. 1.

5, which was 1.7 times as many as that of the control and the 4-CPA. The mean number of cells larger than $200 \mu \mathrm{m}$ per sample on the maximum diameter of the 4-CPA and the CPPU 40 DAA was around 22, which was much larger than that of the control (Fig. 6). The number of cells larger than $200 \mu \mathrm{m}$ per sample 55 DAA was not different among the treatments, however the number of cells smaller than $200 \mu \mathrm{m}$ per sample of the CPPU was 19 , which was 16 and 9 larger than that of the control and the 4-CPA, respectively.

The number of samples in which sucrose content was $40 \mathrm{~g} \mathrm{~L}^{-1}$ or more in the fruit 40 DAA was the largest in the 4-CPA, but the number of samples in which glucose and fructose content was $20 \mathrm{~g} \mathrm{~L}^{-1}$ or more was the largest in the control (Fig. 7). The number of samples in which sucrose content was $100 \mathrm{~g} \mathrm{~L}^{-1}$ or more in the fruit 55 DAA was 0,5 and 2 in the control, the 4-CPA and the CPPU, respectively. The number of samples in which glucose and fructose content was 20 


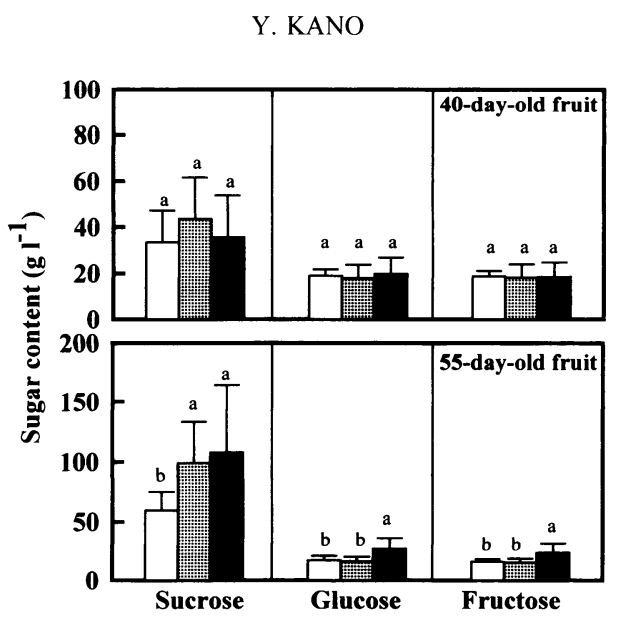

Fig. 8 Comparison of the effects of 4-CPA and CPPU on the mean content of sucrose, glucose and fructose in melon fruits. Open column: control. Dotted column: treated with 4-CPA. Solid column: treated with CPPU. Values with different letters within each sugar are significantly different at $P<0.05$ according to LSD test. Vertical bars are SD $(n=7-8)$.

$\mathrm{g} \mathrm{L}$ ' or more in the fruit of the CPPU 55 DAA was 5 , which were 3 and 5 larger than those of the control and the 4-CPA (Fig. 7). Mean sucrose content per sample of the 4-CPA and the CPPU 40 DAA was not significantly different from the content of the control, but tended to be higher than that of the control (Fig. 8). Mean sucrose content, $99 \mathrm{~g} \mathrm{~L}^{-1}$ of the 4-CPA, and $108 \mathrm{~g} \mathrm{~L}^{-1}$ of the CPPU 55 DAA was about $45 \mathrm{~g} \mathrm{~L}^{-1}$ higher than that of the control (Fig. 8). The mean content of glucose and fructose per sample 40 DAA was around $19 \mathrm{~g} \mathrm{~L}^{-1}$ in all the treatments, however the content of glucose and fructose in the CPPU 55 DAA was about $26 \mathrm{~g} \mathrm{~L}^{-1}$, which was around 10 $\mathrm{g} \mathrm{L}$ ' higher than those of the control and the 4-CPA, respectively.

\section{DISCUSSION}

Fruit weight tended to be large in the 4-CPA-treated fruit. The number of cells larger than 200 $\mu \mathrm{m}$ in the fruits was the largest in those treated with 4-CPA. Auxin accelerates the development of melon fruits (Elassar et al., 1974; Masuda et al., 1990) and cell enlargement (Collet et al., 2000; Jones et al., 1998; Masuda, 1990). From these reports it is reasonable to consider that an increase in fruit weight is caused by cell enlargement by 4-CPA treatment. On the other hand, the weight of the CPPU-treated fruit was almost the same as that of the control. While fruit growth of grapes, kiwi fruits and apples is accelerated by CPPU treatment (Gomi et al., 1997; Nickell, 1986), the growth of melon fruit is not affected by CPPU treatment ( $\mathrm{Li}$ et al., 2000).

Sucrose content in the 4-CPA and the CPPU 55 DAA was about 1.7 times as much as that of the control. The number of cells larger than $200 \mu \mathrm{m}$ in the 4-CPA and the CPPU 40 DAA was mostly 2 times as many as that of the control. The small vacuoles of meristematic cells increase in size and gradually coalesce as the cell enlarges and ages (Esau, 1964), and most of the imported sugars accumulate in the vacuole of sink-tissue storage cells (Leigh et al., 1979; Yamaki and Ino, 1992). Sucrose content in the vacuole of strawberry fruit increases from 25 to 35 DAA (OfosuAnim and Yamaki, 1994). With these results in mind it is reasonable to consider that the content of sucrose accumulated in cells in melon fruit increases due to the coalescence and enlargement of vacuoles by cell enlargement. As mentioned above, 4-CPA has a role in cell enlargement. On the other hand, the cell size of kiwi fruits treated with CPPU is larger than that of the control (Jao et al., 1991; Gomi et al., 1997). Cytokinin-like substances also promote cell enlargement (Denizci, 


\section{4-CPA AND CPPU AFFECT CELL AND SUGAR}

1966). Therefore, it is supposed that the earlier increase of the number of large cells by early 4CPA and CPPU treatment results in the promotion of the active import of sucrose from an early stage of fruit development.

Glucose and fructose contents in the CPPU 55 DAA was more than $23 \mathrm{~g} \mathrm{~L}^{-1}$, compared to around $16 \mathrm{~g} \mathrm{~L}^{-1}$ for the other treatments. The number of cells smaller than $200 \mu \mathrm{m}$ in the CPPU 55 DAA was much larger than the number in the other treatments. Glucose and fructose accumulate exclusively in young melon fruits (Kano, 2000) or mechanically growth-restricted melon fruits (Kano, 2004) with a large number of small cells, and in Japanese pears with a large number of small cells undergoing CPPU treatment (Kano, 2003). Therefore, it can be stated that glucose and fructose accumulation is promoted during the latter period of melon fruits by CPPU treatment due to the abrupt increase of the number of small cells.

From these results, the following conclusion can be made on sugar accumulation of 4-CPAand CPPU-treated melon fruits. Sucrose accumulation is accelerated due to the earlier increase in the number of larger cells in 4-CPA- and CPPU-treated melon fruits. The abrupt increase of the number of small cells during the latter period of the CPPU-treated fruits results in a larger content of glucose and fructose.

I express my gratitude to Dr. Walter A. Newport III, Professor at Ishikawa Agricultural College, for his critical reading of the manuscript, and also to Miss Chikako Miyamura for her technical assistance.

\section{REFERENCES}

Collet, C. E., Harbered, N. P., Leyser, O. 2000. Hormonal interactions in the control of hypocotyl elongation. Plant Physiol. 124: 553-562.

Denizci, R. 1966. Über den Einfluss von Kinetin und Indolylessigsäure auf das Austreiben der Knospen von Pisum sativum. Planta 68: 141-156.

Elassar, G., Rudich, J., Kedar, K. 1974. Parthenocarpic fruit development in muskmelon induced by growth regulators. HortScience 9: 575-580.

Esau, K. 1964. Vacuoles. In: "Plant Anatomy" John Wiley \& Sons, Inc., New York-London-Sydney, p 23-25.

Gomi, A., Hasegawa, I., Hakoda, N., Shimura, I. 1997. Anatomical studies on the fruit development of Actinidia deliciosa (kiwi fruit) treated with CPPU (N-(2-chloro-4-pyridyl)-N-phenylurea). J. Jpn. Soc. Hortic. Sci. 66 (Suppl. 1): 102-103.

Hayata, Y., Doi, M., Akaza, C., Niimi, Y. 1995. Effects of tomato seeds and tomatotone on the growth and IAA contents of tomato. J. Jpn. Soc. Hortic. Sci. 64 (Suppl.1): 292.

Hayata, Y., Li, X. X., Kishimoto, K., Osajima, Y. 2000. Promotion of the growth and improvement of the quality of parthenocarpic and seeded melon fruits by 4-CPA application. J. Jpn. Soc. Hortic. Sci. 69 (Suppl.1): 292.

Hirata, N., Hayashi, S., Ueda, Y. 1969. Studies on the maturing of Japanese pear (I) Promotion of ripening and its mechanism of Japanese pear by black spot. Abst. Jpn. Soc. Hortic. Sci. Spring Meeting: 16-17.

Ikeda, T., Tanabe, K., Banno, K., Tamura, F., Kimura, Y. 1990. Promotion of fruit set and growth by 4PU in melon (Cucumis melo L. cv. Bonas). J. Jpn. Soc. Hortic. Sci. 59 (Suppl. 2): 434-435.

Jao, J., Ohara, H., Matsui, H., Hirata, N. 1991. Physiological studies of the developing fruit of Chinese gooseberry (Actinidia chinensis PLANCH.) II. Effects of KT-30 (1-(2-chloro-4-pyridyl)-3-phenylurea) on fruit growth. Tech. Bull. Fac. Hortic., Chiba Univ. 44: 263-267.

Jones Alan, M., Im, K. H., Savka, M. A., Wu, M. J., De Witt, N. G., Shillito, R., Binns, A. N. 1998. Auxindependent cell expansion mediated by overexpressed auxin-binding protein 1. Science 282: 1114-1117.

Kano, Y. 2000. Relationship between cell size and sucrose accumulation in melon fruits (Cucumis melo L.). J. Jpn. Soc. Hortic. Sci. 69 (Suppl.1): 290.

Kano, Y. 2003. Effects of GA and CPPU treatments on cell size and types of sugars accumulated in Japanese pear fruit. J. Hortic. Sci. Biotech. 78: 331-334.

Kano, Y. 2004. Effect of mechanical restriction of fruit enlargement on cell size and sucrose accumulation in melon fruits (Cucumis melo L.). Acta Hortic. 662: 369-372. 


\section{Y. KANO}

Leigh, R. A., Aprees, T., Fuler, W. A., Bonfild, J. 1979. The location of acid invertase and sucrose in vacuoles isolated from storage roots of red beet (Beta vulgaris L.). Biochem. J. 178: 53-57.

Li, X. X., Hayata, Y., Osajima, Y. 2000. CPPU (re-treatment), 4-CPA and NAA improve the growth and quality of parthenocarpic melon fruit induced by CPPU. Environ. Control Biol. 38: 129-134.

Masuda, M., Nagoa, N., Matsubara, S. 1990. Growth and sugar contents of 2,4-D-induced parthenocarpic melon fruits cv. Earl's favourite. Bull. Okayama Agric. Coll. 75: 15-21.

Masuda, Y. 1990. Auxin-induced cell elongation and cell wall changes. Bot. Mag. 103: 345-370.

Matsui, H., Yuda, E., Nakagawa, S. 1979. Physiological studies on the ripening of Delaware grapes I. Effects of the number of leaves and changes in polysaccharides or organic acids on sugar accumulation in the berries. J. Jpn. Soc. Hortic. Sci. 48: 9-18.

Motomura, Y., Kanahama. K., Saito, T. 1989. Accumulation and metabolism of sugars in melon fruits. J. Jpn. Soc. Hortic. Sci. 58 (Suppl. 2): 294-295.

Nagao, A., Nakazumi, H. 1995. Changes in sugar composition in the growth and ripening of melon fruit. J. Jpn. Soc. Hortic. Sci. 64 (Suppl. 1): 286-287.

Nakagawa, S., Nanjou, Y. 1965. A morphological study of Delaware grape berries. J. Jpn. Soc. Hortic. Sci. 34: 85-95.

Nickell, L. G. 1986. Effects of N-(2-chloro-4-pyridyl)-N-phenylurea on grapes and other crops. In: "Proceeding of the 13th Annual Meeting of the Plant Growth Regulators' Society of America" (ed. by Cooke, A. R.), St Petersberg Beach, FL, p 236-241.

Ofosu-Anim, J., Yamaki, S. 1994. Sugar content, compartmentation and efflux in strawberry tissue. J. Am. Soc. Hortic. Sci. 119: 1024-1028.

Toyama, M., Hayashi, H. 1957. Studies on the fruit development of Japanese pears (I)On the flesh celldivision, cell-enlargement and the relation between flesh cell-size and fruit size in some varieties. J. Jpn. Soc. Hortic. Sci. 25: 62-66.

Yamaki, S., Ino, M. 1992. Alteration of cellular compartmentation and membrane permeability to sugars in immature and mature apple fruit. J. Am. Soc. Hortic. Sci. 117: 951-954. 